\title{
Communication
}

\section{Synthesis and Biological Evaluation of 3-Aryl Pyrazoles as CDK2/HDAC Inhibitor for Anticancer Agents}

\author{
Xianfeng Huang, ${ }^{1,}$, *, Bei Yang ${ }^{1}$, Yuanyuan Liu', Cheng Zhang ${ }^{2}$, Guoqiang Song ${ }^{1}$ \\ ${ }^{1}$ School of Pharmaceutical Engineering \& Life Science, Changzhou University, Changzhou, People's Republic of China \\ ${ }^{2}$ School of Pharmaceutical Sciences, Sun Yat-sen University, Guangzhou, People's Republic of China \\ ${ }^{3}$ Advanced Catalysis and Green Manufacturing Collaborative Innovation Center, Changzhou University, Changzhou, People's Republic of \\ China
}

\author{
Email address: \\ xianfenghh@163.com (Xianfeng Huang) \\ ${ }^{*}$ Corresponding author
}

\section{To cite this article:}

Xianfeng Huang, BeiYang, Yuanyuan Liu, Cheng Zhang, Guoqiang Song. Synthesis and Biological Evaluation of 3-Aryl Pyrazoles as CDK2/HDAC Inhibitor for Anticancer Agents. Journal of Drug Design and Medicinal Chemistry. Vol. 2, No. 4, 2016, pp. 40-46. doi: $10.11648 /$ j.jddmc.20160204.12

Received: May 17, 2016; Accepted: June 20, 2016; Published: August 1, 2016

\begin{abstract}
A novel series of pyrazole derivatives containing hydroxamic acid group were designed and synthesized as multi-target inhibitors targeting CDK2 (cyclin-dependent kinases 2) and HDAC (histone deacetylase). Compounds 6e and 6f exhibited most potent CDK2 inhibition as well as HDAC inhibition. In vitro antiproliferative assay indicated that several compounds showed better antiproliferative potency compared to olomoucine and SAHA. Docking simulation suggested a common mode of interaction at the active binding sites of CDK2 and HDAC, which demonstrates that compound $6 \mathrm{f}$ is a potential agent for cancer therapy deserving further researching.
\end{abstract}

Keywords: Pyrazole, CDK2, HDAC, Inhibior, Anticancer

\section{Introduction}

Protein kinases play pivotal roles in regulating aspects of metabolism, gene expression, cell growth, cell division and cell differentiation through exerting precise and reversible control on protein phosphorylation. $[1,2]$ The regulation of the cell cycle is a well orchestrated pairing of different family members of the Cyclin Dependent Kinases (CDKs) and cyclin regulatory subunits. [3] These kinases upon activation with their cyclins, phosphorylate and modulate the activity of many target substrates such as organizational proteins, transcription factors as well as proteins involved in the replication assembly and machinery of cells. Among these CDKs, CDK2 is especially important, which controls in the majority of cancer cases. [4] In complex with cyclin E, CDK2 plays a paramount role during the G1/S transition of the cell cycle while in complex with cyclin $\mathrm{A}$ it facilitates the progression of the $\mathrm{S}$ phase of the cell cycle. However, so far, the activity observed does not match the initial expectations for CDK inhibitors. [5-7] No CDK inhibitor has been approved for commercial use until now, despite first-in-class clinical compounds, such as the pan-CDK inhibitors Flavopiridol and CY-202 have undergone numerous phase II and phase III clinical trials. [8]

There are several possible explanations for both the modest activity and the toxicity of the CDK inhibitory molecules observed in the clinical setting. Compounds with activity against CDKs and additional kinase targets that might be useful to enhance anti-tumor activity; this group features ZK-304709 (with additional VEGFR1-VEGFR3 and PDGFR-b activity), JNJ-7706621 (CDK1, CDK2 and CDK3 inhibitor with Aurora A/B activity) and GPC-286199 [CDK1, CDK2, CDK3, CDK5, CDK7 and CDK9 inhibitor with additional activity toward CRK (CDK-related kinase)]. [5-9] Among traditional CDK2 inhibitors, pyrazole ring is a promising skeleton that has shown the good anti-CDK2 activity with selective and low toxic properties, such as PNU-292137, 1H-indazole-3-carboxylic acid (4-sulfamoyl 
phenyl)amide and 4-amino-1H-pyrazole-3-carboxylic acid ethyl Este (Figure 1). [10-12] Actually, in our group a series of $\quad N$-((1,3-diphenyl-1H-pyrazol-4-yl)methyl)aniline derivatives have been designed and synthesized, and their biological activities were also evaluated as potential antitumor and cyclin dependent kinase 2 (CDK2) inhibitors. [13] Several compounds displayed high potent CDK2/cyclin E inhibitory activity in vitro.

As a continuation of our effort to obtain more potent anticancer agents, we tried to extend the CDK2 inhibitors mutual interactions by introduction of additional kinase target (HDAC). HDAC inhibitors have also been shown to synergize with other agents, including RTK inhibitors, to suppress proliferation and induce apoptosis in tumor cells. [14-18] For example, two reference compounds, vorinostat and panobinostat, (Figure 1) were used to achieve HDAC and EGFR inhibition, respectively. Actually, in those reported literatures, it was a common strategy that a hydroxamic acid group was linked to another pharmacophore for obtaining multi-target anticancer agents.

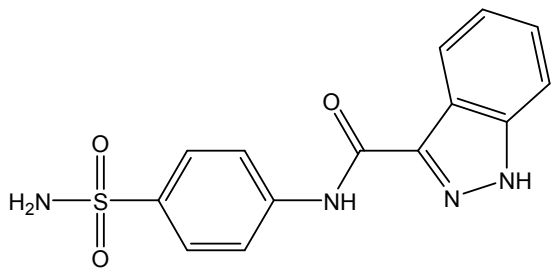

1H-Indazole-3-carboxylic Acid (4-Sulfamoylphenyl)amide<smiles>CCOC(=O)c1n[nH]cc1N</smiles><smiles>O=C(CCCCCCC(=O)Nc1ccccc1)NO</smiles>

4-Amino-1H-pyrazole-3-carboxylic Acid Ethyl Ester<smiles>Cc1[nH]c2ccccc2c1CCNCc1ccc(C=CC(=O)NO)cc1</smiles>

Figure 1. Inhibitors of CDK2 with pyrazole core and HDAC.

We wondered whether there would be any advantage for a CDK2 inhibitor connected with a hydroxamic acid group could serve as both a CDK2 and HDAC inhibitor. Herein, a series of CDK/HDAC inhibitors containing pyrazole ring and hydroxamic acid group was synthesized. This work describes our efforts in exploring a CDK2/HDAC inhibitor for anticancer agents represented by structure1, which shows excellent activities against both CKD2 and HDAC.<smiles>CO[N+]([O-])(Cl)CSC(=O)c1ccccc1</smiles><smiles>[R]NCc1cn(C)nc1-c1ccccc1</smiles><smiles>C/C(=N/NC(N)=O)c1ccccc1</smiles>

2<smiles>O=Cc1c[nH]nc1-c1ccccc1</smiles>

\section{3}<smiles>[R]NCc1c[nH]nc1-c1ccccc1-c1nn(C(=O)C(=O)OCC)cc1CN[R]</smiles>

Figure 2. General synthesis of 6a-6i. 


\section{Synthesis}

The synthetic route of the 3-aryl pyrazole derivatives with hydroxamic acid group (6a-6i) are outlined in Figure 2. [13, 19] Firstly, acetophenone as starting material was conversed to semicarbazone 2, which was formylated under the action of $\mathrm{POCl}_{3}$ and DMF to form the 3-aryl pyrazole-4-carboxaldehydes 3.4 was synthesized from 3 and various amines by direct reductive amination using $\mathrm{NaBH}_{4}$ as a reducing agent. Ethyl acetate was introduced through electrophilic substitution reaction by Ethyl bromoacetate in good yield. And the esters were replaced with $\mathrm{NH}_{2} \mathrm{OH}$ to afford the target compounds. The synthetic compounds gave satisfactory elementary analytical and spectroscopic data. ${ }^{1} \mathrm{H}$ NMR and ESI-MS spectra were consistent with the assigned structures.

\section{Biological Evaluation}<smiles>[R]NCc1cn(C)nc1-c1ccccc1</smiles>

Figure 3. The chemical structure of $6 a-6 i$.

Table 1. Inhibition of CDK2/cyclinE and HDAC and antiproliferative activity towards MCF-7 and B16-F10 cellines of 6a-6i.

\begin{tabular}{|c|c|c|c|c|c|c|}
\hline \multirow{2}{*}{ Compounds } & \multirow{2}{*}{$\mathbf{n}$} & \multirow{2}{*}{$\mathbf{R}$} & \multicolumn{4}{|l|}{$\mathrm{IC}_{50}(\mu \mathrm{M})$} \\
\hline & & & CDK2 & HDAC & MCF-7 & B16-F10 \\
\hline $6 a$ & 1 & & $6.79 \pm 0.09$ & $38 \pm 0.9$ & $17.86 \pm 0.19$ & $8.24 \pm 0.6$ \\
\hline $6 \mathrm{~b}$ & 1 & & $0.82 \pm 0.03$ & $35 \pm 1.3$ & $10.82 \pm 0.13$ & $5.23 \pm 0.04$ \\
\hline $6 c$ & 1 & & $1.86 \pm 0.03$ & $29 \pm 0.8$ & $8.88 \pm 0.41$ & $39.2 \pm 0.9$ \\
\hline $6 \mathrm{~d}$ & 3 & & $10.88 \pm 1.17$ & $19.8 \pm 0.98$ & $5.32 \pm 0.11$ & $21.3 \pm 0.87$ \\
\hline $6 e$ & 3 & & $4.63 \pm 0.06$ & $3.7 \pm 0.53$ & $1.12 \pm 0.05$ & $3.90 \pm 0.35$ \\
\hline $6 f$ & 3 & & $2.95 \pm 0.02$ & $2.76 \pm 0.08$ & $2.96 \pm 0.03$ & $2.53 \pm 0.06$ \\
\hline $6 \mathrm{~g}$ & 6 & & $36.79 \pm 1.88$ & $0.62 \pm 0.03$ & $16.79 \pm 1.28$ & $3.23 \pm 0.03$ \\
\hline $6 \mathrm{~h}$ & 6 & & $10.82 \pm 0.93$ & $8.33 \pm 0.51$ & $13.77 \pm 0.13$ & $9.31 \pm 0.21$ \\
\hline $6 \mathrm{i}$ & 6 & & $17.86 \pm 0.92$ & $10.3 \pm 0.12$ & $6.96 \pm 0.03$ & $5.13 \pm 0.01$ \\
\hline Olomoucine & & & $4.11 \pm 0.07$ & $37 \pm 0.8$ & $2.19 \pm 0.01$ & $0.82 \pm 0.01$ \\
\hline SAHA & & & $26 \pm 0.5$ & $0.95 \pm 0.02$ & $10.55 \pm 0.17$ & $7.33 \pm 0.07$ \\
\hline
\end{tabular}


The enzymatic inhibitory activities of the target compounds were evaluated in CDK2 and HDAC kinase activity assays. The results were summarized in Figure 3 and Table 1. As shown in the Table, all the target compounds showed moderate to potent CDK2 inhibitory activities, with $\mathrm{IC}_{50}$ values ranging from 0.82 to $36.79 \mu \mathrm{M}$. Compounds $6 \mathrm{~b}, 6 \mathrm{c}$ and $6 \mathrm{f}$ showed strong inhibitory effect $\left(\mathrm{IC}_{50}=0.82 \pm 0.03 \mu \mathrm{M}, 1.86 \pm 0.03 \mu \mathrm{M}\right.$ and $2.95 \pm 0.02 \mu \mathrm{M}$, respectively), which were better than that of Olomoucine $\left(\mathrm{IC}_{50}=4.11 \pm 0.07 \mu \mathrm{M}\right)$. For the HDAC inhibitory activities, it was marginally affected by the length of linker, as indicated by the comparison of three groups of compounds (compounds 6a-6c, compounds 6d-6f and compounds 6g-6i). The optimal carbon chain length seems to be six, which gives an $\mathrm{IC}_{50}$ of HDAC inhibition similar to that of SAHA. Compound $6 \mathrm{~g}$ exhibited the most potent HDAC inhibition, with an $\mathrm{IC}_{50}$ value of $0.62 \mu \mathrm{M}$. In contrast, the data suggested that the carbon chain length was not so critical for CDK2 inhibition. Even though, when the carbon chain was too long $(\mathrm{n}=6)$, the CDK2 inhibitory activities decreased to a certain extent. Therefore, the chain length of 3 carbon atoms may be a suitable connecting point for CDK2 inhibitory activities, without sacrificing HDAC inhibitory activities. Just as that indicated in Table 1, only compounds $6 \mathrm{e}$ and $6 \mathrm{f}$ exhibited potent CDK2 inhibition as well as HDAC.

To further ascertain the utility of hetero aromatic HDAC inhibitors at the cellular level, MCF-7 and B16-F10 cellines were selected for evaluation, Table 1 showed their $\mathrm{IC}_{50}$ values. Part of the target compounds exhibited similar or superior antiproliferative effect to Olomoucine and SAHA. From the results, to a certain degree, the correlation between the in vitro and in cell $\mathrm{IC}_{50}$ values was observed. Compounds $6 \mathrm{e}$ and $6 \mathrm{f}$ exhibited the high potent antiproliferative activities against both MCF-7 and B16-F10 cells, which was similar to SAHA and SB1317. The greater cellular potency of $6 \mathrm{e}$ and $6 \mathrm{f}$ may be attributed to the synergistic effects resulting from simultaneous inhibition of HDAC and CDK2. This result indicated the anti-proliferative effect was produced partly by connection of $\mathrm{CDK} 2 / \mathrm{HDAC}$ protein and the compounds.

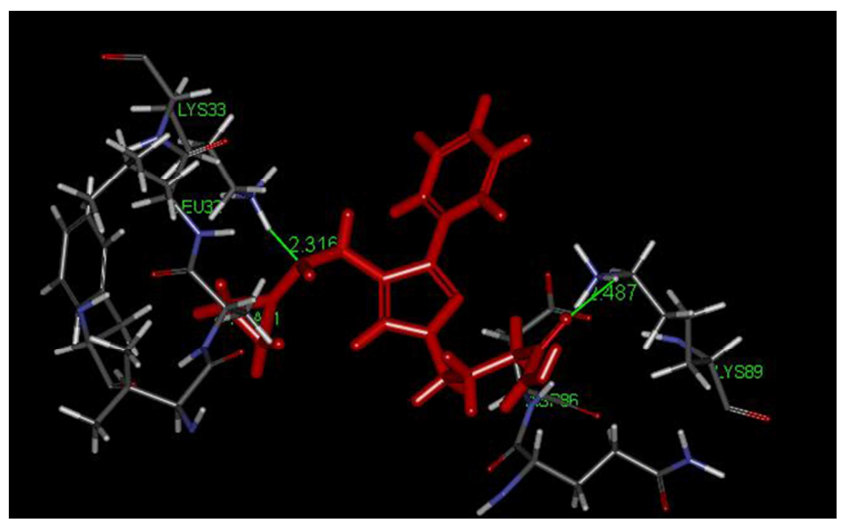

Figure 4. Compound of (colored red) is bond into ATP binding sites of CDK2 (entry $1 \mathrm{HOV}$ in the Protein Data Bank). The blue lines show the hydrogen bonds.

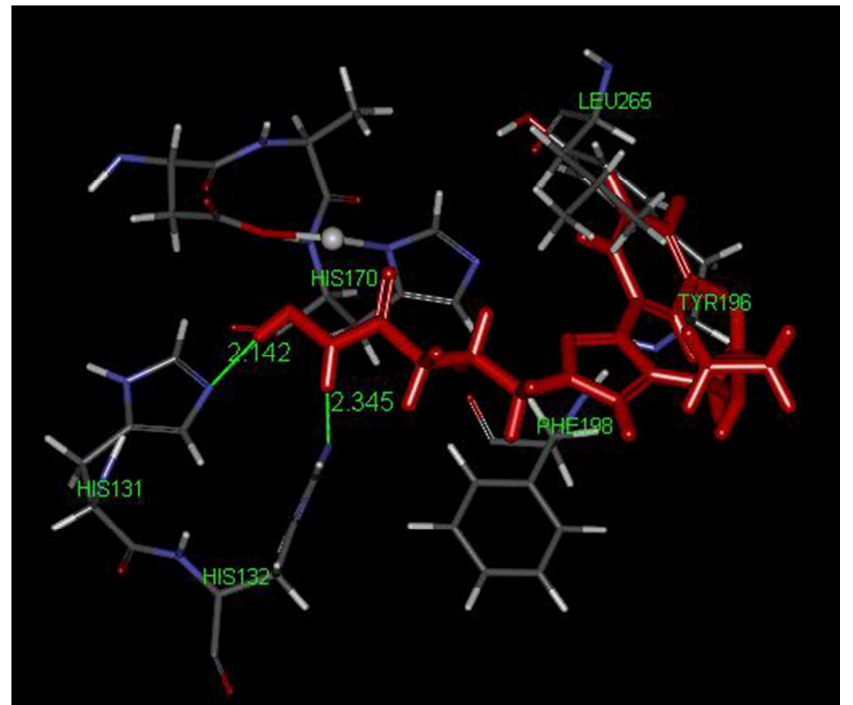

Figure 5. Compound $6 f$ (colored red) is bond into the active sites of HDLP (entry 1C3S in the Protein Data Bank). The blue lines show the hydrogen bonds.

To gain better understanding on the possible binding modes of the synthesized target compounds on CDK2 and HDAC, we proceeded to examine the interaction of these compounds with CDK2 and HDAC. All docking runs were applied CDOCKER protocol of Discovery Studio 2.5, and the compound $6 \mathrm{f}$ was selected as the representative compound. Fig. 4 demonstrates the compound $6 \mathrm{f}$ docking into the ATP binding cavity of CDK2 (PDB code: $1 \mathrm{H} 0 \mathrm{~V}$ ). In the binding mode, compound $6 \mathrm{f}$ is nicely bound to the ATP binding site of CDK2 via two hydrogen bonds. The nitrogen atom near to cyclopropyl formed one hydrogen bond with the amino group hydrogen of LYS 33 (bond length: $2.316 \AA$ ). The oxygen atom of the amide bond formed another hydrogen bond with the amino group hydrogen of LYS 89 (bond length: $2.478 \AA$ ). The binding model of compound $6 \mathrm{f}$ into the binding site of HDLP (Histone Deacetylase-Like Protein, PDB code: 1C3S) is depicted in Fig.5. In this binding model, the two hydrogen atoms of hydroxamic acid group of compound $6 \mathrm{f}$ forms two hydrogen bonds with the active hydrogen atom on imidazole ring of His 131 (bond length: $2.142 \AA$ ) and His 132 (bond length: $2.345 \AA$ ), respectively. In addition, it is obvious that the aromatic rings at the other end of the aliphatic chain is well tolerated. The nice binding model of compound $6 \mathrm{f}$ with CDK2 and HDLP indicates that compound $6 f$ could be a potent dual CDK2/HDAC inhibitor.

\section{Conclusion}

In summary, several novel pyrazole derivatives containing an hydroxamic acid group simultaneously inhibiting CDK2 and HDAC were conceived, synthesized, and evaluated in vitro. Most of the compounds exhibited potent CDK2 or HDAC inhibitory activities and antiproliferative activities against MCF-7 and B16-F10 cells. Among all of the compounds, only compounds $6 \mathrm{e}$ and $6 \mathrm{f}$ exhibited potent 
CDK2 and HDAC inhibition simultaneously. The two compounds may display promise as multi-target anticancer agent, and have been selected for further study as novel anticancer agents.

\section{Experiments}

\subsection{Materials and Measurements}

All the NMR spectra were recorded on a Bruker DRX 400 model Spectrometer in $\mathrm{CDCl}_{3}$, and chemical shifts were reported in $\operatorname{ppm}(\delta)$. ESI-MS spectra were recorded on a Mariner System 5304 Mass spectrometer. Elemental analyses were performed on a CHN-O-Rapid instrument. Melting points were measured on a Boetius micro melting point apparatus. All compounds were purified by recrystallization, column chromatography or reverse phase chromatography. Column chromatography was performed on silica gel (200-300 mesh). TLC was run on the silica gel coated aluminum sheets (Silica Gel 60 GF254, E. Merk, Germany) and visualized in UV light $(254 \mathrm{~nm})$.

\subsection{Synthesis of (E)-1-(1-Phenylethylidene)Semicarbazide (2)}

A thoroughly ground mixture of $100 \mathrm{~g}$ of semicarbazide hydrochloride and $100 \mathrm{~g}$ of anhydrous sodium acetate was suspended in 11 of ethanol, and the suspension was refluxed for $45 \mathrm{~min}$ and filtered while hot. Acetophenone, $0.83 \mathrm{~mol}$, was added to the mother liquor under reflux, and the mixture was refluxed for $1 \mathrm{~h}$, cooled to $20^{\circ} \mathrm{C}$, allowed to stand for 10 $\mathrm{h}$, and the precipitate that formed was filtered off, washed with a little ethanol cooled to $5^{\circ} \mathrm{C}$, and dried to isolate semicarbazone.

Yield: 93\%, white solid, MS (ESI): $178.3\left(\mathrm{C}_{9} \mathrm{H}_{12} \mathrm{~N}_{3} \mathrm{O}\right.$, $\left.[\mathrm{M}+\mathrm{H}]^{+}\right)$. Anal. Calcd. for $\mathrm{C}_{9} \mathrm{H}_{11} \mathrm{~N}_{3} \mathrm{O}$ : C61.00, H6.26, $\mathrm{N} 23.71 \%$. Found: C61.63, H6.32, N23.62\%. ${ }^{1} \mathrm{H} \quad \mathrm{NMR}$ (500MHz, DMSO- $\left.d_{6}, \delta \mathrm{ppm}\right): 2.18(\mathrm{~s}, 3 \mathrm{H}), 6.47(\mathrm{~m}, 2 \mathrm{H})$, $7.35(\mathrm{~m}, 3 \mathrm{H}), 7.83(\mathrm{~m}, 2 \mathrm{H}), 9.31(\mathrm{~s}, 1 \mathrm{H})$.

\subsection{3-Phenyl-1H-Pyrazole-4-Carbaldehyde (3)}

Freshly distilled $\mathrm{POCl}_{3}, 353 \mathrm{~g}$, was added dropwise at $0^{\circ} \mathrm{C}$ to $440 \mathrm{ml}$ of dry DMF. The mixture was allowed to stand for $20 \mathrm{~min}$ at $20{ }^{\circ} \mathrm{C}$ and cooled to $0^{\circ} \mathrm{C}$, after which 1 mol of semicarbazone was added so as the temperature of the reaction mixture did not rise over $40-50^{\circ} \mathrm{C}$ and uniform gas evolution was observed. After all semicarbazone had been added, the mixture was stirred for $1.5 \mathrm{~h}$ at $80^{\circ} \mathrm{C}$ and quickly poured onto $1.5 \mathrm{~kg}$ of ice. The mixture was treated with $30 \%$ aqueous $\mathrm{NaOH}$ to $\mathrm{pH} 8-9$, allowed to stand for $30 \mathrm{~min}$, and treated with conc. $\mathrm{HCl}$ until heterogenization ( $\mathrm{pH} 5-7)$. After $18 \mathrm{~h}$, the solid material was separated, washed with water, and dried at $50^{\circ} \mathrm{C}$ to obtain 3 .

Yield 91\%, yellow powders, MS (ESI): $173.5\left(\mathrm{C}_{10} \mathrm{H}_{9} \mathrm{~N}_{2} \mathrm{O}\right.$, $\left.[\mathrm{M}+\mathrm{H}]^{+}\right)$. Anal. Calcd. For $\mathrm{C}_{9} \mathrm{H}_{8} \mathrm{~N}_{2} \mathrm{O}:$ C69.76, H4.68, N16.27\%. Found: C69.08, H4.62, N16.39\%. ${ }^{1} \mathrm{H}$ NMR (500 $\left.\mathrm{MHz}, \mathrm{DMSO}-d_{6}, \delta \mathrm{ppm}\right): 7.50(\mathrm{~m}, 3 \mathrm{H}), 7.82(\mathrm{~m}, 2 \mathrm{H}), 8.36$ (s, 1H), $9.90(\mathrm{~s}, 1 \mathrm{H}), 13.58(\mathrm{~m}, 1 \mathrm{H})$.

\subsection{3-Phenyl-1H-Pyrazole-4-Carbaldehyde (6a-6i)}

Compound 3 ( $1 \mathrm{mmol}$ ) was dissolved in $5 \mathrm{ml}$ of ethanol, and various amines was added to the solution. The reaction mixture was refluxed for $30 \mathrm{~min}$, and cooled to room temperature. $\mathrm{NaBH}_{4}$ of $0.5 \mathrm{mmol}$ was added to the reaction solution slowly, and stirred at room temperature for $2 \mathrm{~h}$. The mixture was evaporated under vacuum, and dissolved in dichloromethane $(5 \mathrm{ml})$. The solution was washed with saturated $\mathrm{NaCl}$ solution and water, respectively, dried over anhydrous sodium sulfate, and evaporated to afford 4 . Compound 4 could be used in the next step with no purification.

Compound 4 (0.256 g, $1 \mathrm{mmol})$, proportional ethyl bromoacetate, and $\mathrm{K}_{2} \mathrm{CO}_{3}$ in $50 \mathrm{ml}$ of dry $\mathrm{CH}_{3} \mathrm{CN}$ were stirred at reflux for 2-3 h. After the completion of reaction, the soln. was added to a mixture of ice and $\mathrm{H}_{2} \mathrm{O}$, and the yellow solution was extracted with three $10-\mathrm{ml}$ portions of AcOEt. The combined organic layers were washed with $\mathrm{H}_{2} \mathrm{O}$, dried $\left(\mathrm{Na}_{2} \mathrm{SO}_{4}\right)$, filtered, and evaporated to afford 5 .

A solution of hydroxyl amine hydrochloride $(271 \mathrm{mg}, 3.9$ $\mathrm{mmol}$ ) in $10 \mathrm{~mL}$ of $\mathrm{MeOH}, \mathrm{KOH}(219 \mathrm{mg}, 3.9 \mathrm{mmol})$ was added and stirred at $40^{\circ} \mathrm{C}$ for $10 \mathrm{~min}$. The reaction mixture was cooled to $0^{\circ} \mathrm{C}$ and filtered. Compound $5(10 \mathrm{mg}, 0.02$ $\mathrm{mmol})$ was added to the filtrate followed by $\mathrm{KOH}(0.04$ $\mathrm{mmol}$ ) at room temperature for 3 hours. The reaction mixture was extracted with EtOAc. The organic layer was washed with saturated $\mathrm{NH}_{4} \mathrm{Cl}$ solution and brine, and dried over $\mathrm{MgSO}_{4}$, filtered and concentrated. The residue was purified by reverse phase preparative HPLC.

2-(4-((benzylamino)methyl)-3-phenyl-1H-pyrazol-1-yl)-Nhydroxyacetamide (6a)

Pale solid, m.p.: $251-253^{\circ} \mathrm{C} . \mathrm{MS}(\mathrm{ESI}): 337.2\left(\mathrm{C}_{19} \mathrm{H}_{21} \mathrm{~N}_{4} \mathrm{O}_{2}\right.$, $\left.[\mathrm{M}+\mathrm{H}]^{+}\right)$. Anal. Calcd. for $\mathrm{C}_{19} \mathrm{H}_{20} \mathrm{~N}_{4} \mathrm{O}_{2}:$ C67.84, H5.99, N16.66\%. Found: C67.72, H5.91, N16.58\%. ${ }^{1} \mathrm{H}$ NMR (500 $\left.\mathrm{MHz}, \mathrm{DMSO}-d_{6}, \delta \mathrm{ppm}\right): 2.97(\mathrm{~s}, 2 \mathrm{H}), 3.75(\mathrm{~m}, 4 \mathrm{H})$, 7.21-7.40 (m, 8H), 7.67-7.75 (m, 3H), $8.78(\mathrm{~s}, 1 \mathrm{H}), 10.29(\mathrm{~s}$, $1 \mathrm{H}), 12.86(\mathrm{~s}, 1 \mathrm{H})$.

2-(4-((cyclohexylamino)methyl)-3-phenyl-1H-pyrazol-1-yl) -N-hydroxyacetamide (6b)

White solid, m.p.: $222-223^{\circ} \mathrm{C}$. MS (ESI): 329.6 $\left(\mathrm{C}_{18} \mathrm{H}_{25} \mathrm{~N}_{4} \mathrm{O}_{2},[\mathrm{M}+\mathrm{H}]^{+}\right)$. Anal. Calcd. for $\mathrm{C}_{18} \mathrm{H}_{24} \mathrm{~N}_{4} \mathrm{O}_{2}$ : C65.83, H7.37, N17.06\%. Found: C65.26, H7.31, N17.19\%. ${ }^{1} \mathrm{H}$ NMR (500 MHz, DMSO- $\left.d_{6}, \delta \mathrm{ppm}\right): 1.06-1.24(\mathrm{~m}, 5 \mathrm{H}), 1.67-1.76$ $(\mathrm{m}, 5 \mathrm{H}), 2.49(\mathrm{~m}, 1 \mathrm{H}), 3.00(\mathrm{~s}, 2 \mathrm{H}), 3.66(\mathrm{~s}, 2 \mathrm{H}), 7.34(\mathrm{~m}$, 1H), $7.42(\mathrm{~m}, 2 \mathrm{H}), 7.70(\mathrm{~m}, 3 \mathrm{H}), 8.67(\mathrm{~s}, 1 \mathrm{H}), 9.87(\mathrm{~s}, 1 \mathrm{H})$, $12.78(\mathrm{~s}, 1 \mathrm{H})$.

N-hydroxy-2-(4-((isobutylamino)methyl)-3-phenyl-1H-pyr azol-1-yl)acetamide (6c)

White solid, m.p.: 245-247 ${ }^{\circ} \mathrm{C}$. MS (ESI): 303.6 $\left(\mathrm{C}_{16} \mathrm{H}_{23} \mathrm{~N}_{4} \mathrm{O}_{2},[\mathrm{M}+\mathrm{H}]^{+}\right)$. Anal. Calcd. for $\mathrm{C}_{16} \mathrm{H}_{22} \mathrm{~N}_{4} \mathrm{O}_{2}$ : C63.55, H7.33, N18.53\%. Found: C63.68, H7.39, N18.66\%. ${ }^{1} \mathrm{H}$ NMR (500 MHz, DMSO- $\left.d_{6}, \delta p p m\right): 0.77(\mathrm{~m}, 6 \mathrm{H}), 1.72(\mathrm{~m}, 1 \mathrm{H})$, $2.25(\mathrm{~m}, 2 \mathrm{H}), 2.98(\mathrm{~m}, 2 \mathrm{H}), 3.67(\mathrm{~m}, 2 \mathrm{H}), 7.31-7.52(\mathrm{~m}, 3 \mathrm{H})$, 7.74-7.81 (m, 3H), $8.75(\mathrm{~s}, 1 \mathrm{H}), 10.20(\mathrm{~s}, 1 \mathrm{H}), 12.77(\mathrm{~s}, 1 \mathrm{H})$. 4-(4-((benzylamino)methyl)-3-phenyl-1H-pyrazol-1-yl)-Nhydroxybutanamide (6d) 
Pale solid, m.p.: $215-217^{\circ} \mathrm{C}$. MS (ESI): $365.8\left(\mathrm{C}_{21} \mathrm{H}_{25} \mathrm{~N}_{4} \mathrm{O}_{2}\right.$, $\left.[\mathrm{M}+\mathrm{H}]^{+}\right)$. Anal. Calcd. for $\mathrm{C}_{21} \mathrm{H}_{24} \mathrm{~N}_{4} \mathrm{O}_{2}$ : C69.21, H6.64, N15.37\%. Found: C68.65, H6.69, N15.21\%. ${ }^{1} \mathrm{H}$ NMR (500 MHz, DMSO- $\left.d_{6}, \delta p p m\right): 1.66(\mathrm{~m}, 2 \mathrm{H}), 1.83(\mathrm{~m}, 2 \mathrm{H}), 2.34(\mathrm{~m}$, 2H), $3.49(\mathrm{~m}, 4 \mathrm{H}), 7.17-7.37(\mathrm{~m}, 8 \mathrm{H}), 7.71(\mathrm{~m}, 3 \mathrm{H}), 8.63(\mathrm{~s}$, $1 \mathrm{H}), 10.28(\mathrm{~s}, 1 \mathrm{H}), 12.83(\mathrm{~s}, 1 \mathrm{H})$.

4-(4-((cyclohexylmethylamino)methyl)-3-phenyl-1H-pyraz ol-1-yl)-N-hydroxybutanamide (6e)

White solid, m.p.: $199-201^{\circ} \mathrm{C}$. MS (ESI): 371.2 $\left(\mathrm{C}_{21} \mathrm{H}_{31} \mathrm{~N}_{4} \mathrm{O}_{2},[\mathrm{M}+\mathrm{H}]^{+}\right)$. Anal. Calcd. for $\mathrm{C}_{21} \mathrm{H}_{30} \mathrm{~N}_{4} \mathrm{O}_{2}$ : C68.08, H8.16, N15.12\%. Found: C68.23, H8.19, N15.03\%. ${ }^{1} \mathrm{H}$ NMR (500 MHz, DMSO- $\left.d_{6}, \delta p p m\right): 1.03-1.22(\mathrm{~m}, 8 \mathrm{H}), 1.53(\mathrm{~m}$, 2H), $1.67(\mathrm{~m}, 2 \mathrm{H}), 1.89(\mathrm{~m}, 2 \mathrm{H}), 2.39(\mathrm{~m}, 3 \mathrm{H}), 3.53(\mathrm{~m}, 2 \mathrm{H})$, $7.40(\mathrm{~m}, 4 \mathrm{H}), 7.81(\mathrm{~m}, 2 \mathrm{H}), 8.62(\mathrm{~s}, 1 \mathrm{H}), 10.28(\mathrm{~s}, 1 \mathrm{H}), 12.98$ (s, 1H).

$N$-hydroxy-4-(4-((isobutylamino)methyl)-3-phenyl-1H-pyr azol-1-yl)butanamide (6f)

White solid, m.p.: $190-191^{\circ} \mathrm{C}$. MS (ESI): 331.7 $\left(\mathrm{C}_{18} \mathrm{H}_{27} \mathrm{~N}_{4} \mathrm{O}_{2}\right.$, $\left.[\mathrm{M}+\mathrm{H}]^{+}\right)$. Anal. Calcd. for $\mathrm{C}_{18} \mathrm{H}_{26} \mathrm{~N}_{4} \mathrm{O}_{2}$ : C65.43, H7.93, N16.96\%. Found: C65.31, H7.99, N16.82\%. ${ }^{1} \mathrm{H}$ NMR (500 MHz, DMSO- $\left.d_{6}, \delta p p m\right): 0.76(\mathrm{~m}, 6 \mathrm{H}), 1.60(\mathrm{~m}, 3 \mathrm{H})$, $2.14(\mathrm{~m}, 2 \mathrm{H}), 2.27(\mathrm{~m}, 2 \mathrm{H}), 2.40(\mathrm{~m}, 2 \mathrm{H}), 3.48(\mathrm{~m}, 2 \mathrm{H})$, 7.35-7.70 (m, 3H), $7.72(\mathrm{~s}, 1 \mathrm{H}), 7.91(\mathrm{~m}, 2 \mathrm{H}), 8.61(\mathrm{~s}, 1 \mathrm{H})$, $10.43(\mathrm{~s}, 1 \mathrm{H}), 12.87(\mathrm{~s}, 1 \mathrm{H})$.

7-(4-((benzylamino)methyl)-3-phenyl-1H-pyrazol-1-yl)- $N$ hydroxyheptanamide $(6 \mathrm{~g})$

White solid, m.p.: $196-198^{\circ} \mathrm{C}$. MS (ESI): 407.2 $\left(\mathrm{C}_{24} \mathrm{H}_{31} \mathrm{~N}_{4} \mathrm{O}_{2},[\mathrm{M}+\mathrm{H}]^{+}\right)$. Anal. Calcd. for $\mathrm{C}_{24} \mathrm{H}_{30} \mathrm{~N}_{4} \mathrm{O}_{2}: \mathrm{C} 70.91$, H7.44, N13.78\%. Found: C70.73, H7.52, N13.89\%. ${ }^{1} \mathrm{H}$ NMR (500 MHz, DMSO- $\left.d_{6}, \delta p p m\right): 1.71-1.74(\mathrm{~m}, 2 \mathrm{H}), 1.39-1.58$ $(\mathrm{m}, 4 \mathrm{H}), 1.27(\mathrm{~m}, 2 \mathrm{H}), 2.24(\mathrm{~m}, 2 \mathrm{H}), 2.40(\mathrm{~m}, 2 \mathrm{H}), 3.54(\mathrm{~s}$, $2 \mathrm{H}), 3.57(\mathrm{~s}, 2 \mathrm{H}), 7.23-7.37(\mathrm{~m}, 8 \mathrm{H}), 7.61-7.73(\mathrm{~m}, 3 \mathrm{H}), 8.63$ (s, 1H), $10.42(\mathrm{~s}, 1 \mathrm{H}), 12.93(\mathrm{~s}, 1 \mathrm{H})$.

7-(4-((cyclohexylamino)methyl)-3-phenyl-1H-pyrazol-1-yl) -N-hydroxyheptanamide (6h)

White solid, m.p.: $160-162^{\circ} \mathrm{C}$. MS(ESI): 399.7 $\left(\mathrm{C}_{23} \mathrm{H}_{35} \mathrm{~N}_{4} \mathrm{O}_{2},[\mathrm{M}+\mathrm{H}]^{+}\right)$. Anal. Calcd. for $\mathrm{C}_{23} \mathrm{H}_{34} \mathrm{~N}_{4} \mathrm{O}_{2}$ : C69.31, H8.60, N14.06\%. Found: C69.59, H8.51, N14.18\%. ${ }^{1} \mathrm{H}$ NMR (500 MHz, DMSO- $\left.d_{6}, \delta p p m\right): 1.66-1.80(\mathrm{~m}, 4 \mathrm{H}), 1.57(\mathrm{~m}$, $3 \mathrm{H}), 1.30-1.48(\mathrm{~m}, 7 \mathrm{H}), 1.17(\mathrm{~m}, 4 \mathrm{H}), 2.25(\mathrm{~m}, 2 \mathrm{H}), 2.42(\mathrm{~m}$, 2H), $2.64(\mathrm{~m}, 1 \mathrm{H}), 3.64(\mathrm{~s}, 2 \mathrm{H}), 7.46(\mathrm{~m}, 4 \mathrm{H}), 7.83(\mathrm{~m}, 2 \mathrm{H})$, 8.59 (s, 1H), 10.33 (s, 1H), $13.04(\mathrm{~s}, 1 \mathrm{H})$.

N-hydroxy-7-(4-((isobutylamino)methyl)-3-phenyl-1H-pyr azol-1-yl)heptanamide (6i)

White solid, m.p.: $187-189^{\circ} \mathrm{C}$. MS (ESI): 373.2 $\left.\left(\mathrm{C}_{23} \mathrm{H}_{35} \mathrm{~N}_{4} \mathrm{O}_{2} \text {, [M+H] }\right]^{+}\right)$. Anal. Calcd. for $\mathrm{C}_{23} \mathrm{H}_{34} \mathrm{~N}_{4} \mathrm{O}_{2}$ : C67.71, H8.66, N15.04\%. Found: C67.23, H8.62, N15.17\%. ${ }^{1} \mathrm{H}$ NMR $\left(500 \mathrm{MHz}, \mathrm{DMSO}-d_{6}, \delta \mathrm{ppm}\right): 0.79(\mathrm{~m}, 6 \mathrm{H})$, 1.72-1.76 (m, 2H), 1.37-1.52 (m, 4H), 1.27-1.33 (m, 3H), $2.25(\mathrm{~m}, 2 \mathrm{H}), 2.29(\mathrm{~m}, 2 \mathrm{H}), 2.43(\mathrm{~m}, 2 \mathrm{H}), 3.67(\mathrm{~s}, 2 \mathrm{H})$, 7.33-7.68 (m, 3H), 7.76-7.83 (m, 3H), 8.65 (s, 1H), 10.29 (s, $1 \mathrm{H}), 12.92(\mathrm{~s}, 1 \mathrm{H})$.

\subsection{Antiproliferation Assay}

The antiproliferative activities of the prepared compounds against MCF-7 and B16-F10 cells were evaluated as described elsewhere with some modifications. [20] Target tumor celllines were grown to logphase in RPMI1640 medium supplemented with $10 \%$ fetal bovine serum. After diluting to $2 \times 10^{4}$ cells $\mathrm{mL}^{-1}$ with the complete medium, 100 $\mu \mathrm{L}$ of the obtained cell suspension was added to each well of 96-well culture plates. The subsequent incubation was permitted at $37^{\circ} \mathrm{C}, 5 \% \mathrm{CO}_{2}$ atmosphere for $24 \mathrm{~h}$ before the cytotoxicity assessments. Tested samples at pre-set concentrations were added to six wells with Olomoucine as positive references. After $48 \mathrm{~h}$ exposure period, $40 \mu \mathrm{L}$ of PBS

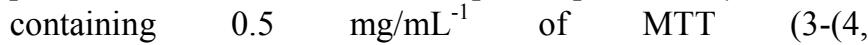
5-dimethylthiazol-2-yl)-2, 5-diphenyltetrazolium bromide)) was added to each well. After $4 \mathrm{~h}$ incubation, the optical absorbance was measured at $570 \mathrm{~nm}$ on an ELISA microplate reader. In all experiments three replicate wells were used for each drug concentration. Each assay was carried out for at least three times.

\subsection{CDK2/CyclinE and HDAC Inhibition Assay}

The ability of the test compounds $6 a-6 i$ to inhibit CDK2/cyclinE was determined according to the reported method. [21] The HDAC inhibitory activities were assessed using the Biomol FluordeLys assaykit (AK-500, Enzo Life Sciences, Inc.), as previously described by us $[20,21] .[22,23]$

\section{Acknowledgments}

This work was supported by the Youth Natural Science Foundation of Jiangsu Province (BK20130248).

\section{Competing Interests}

The authors declare that there is no conflict of interest regarding the publication of this article.

\section{References}

[1] Blume-Jensen, P.; Hunter, T. Oncogenic kinase signaling. Nature, 2001, 411(6835), 355-365.

[2] Manning, G.; Whyte, D. B.; Martinez, R.; Hunter, T.; Sudarsanam, S. The protein kinase complement of the human genome. Science, 2002, 298, 1912-1934.

[3] Harper, J. W.; Adams, P. D. Cyclin-dependent kinases. Chem. Rev., 2001, 101, 2511-2526.

[4] Tetsu, O.; McCormick, F. Proliferation of cancer cells despite CDK2 inhibition. Cancer Cell, 2003, 3, 233-245.

[5] Shapiro, G.I. Cyclin-dependent kinase path ways as targets for cancer treatment. J. Clin. Oncol., 2006, 24, 1770-1783.

[6] Misra, R. N. Clinical progress of selective cyclin-dependent kinase (CDK) inhibitors. Drugs of the Future, 2006, 31(1), $43-52$.

[7] Castoldi, R. E.; Pennella, G.; Saturno, G. S.; Grossi, P.; Brughera, M.; Venturi, M. Assessing and managing toxicities induced by kinase inhibitors. Curr. Opin. Drug Disc. Dev., $2007,10,53-57$. 
[8] Byrd, J. C.; Lin, T. S.; Dalton, J. T.; Wu, D.; Phelps, M. A.; Fischer, B.; Moran, M.; Blum, K.A.; Rovin, B.; Brooker-McEldowney, M.; Broering, S.; Schaaf, L.J.; Johnson, A.J.; Lucas, D. M.; Heerema, N. A.; Lozanski, G.;Young, D.C.; Suarez, J.R.; Colevas, A.D.; Grever, M.R. Flavopiridol administered using a pharmacologically derived schedule is associated with marked clinical efficacy inrefractory, genetically high-risk chronicly mphocytic leukemia. Blood, 2007, 15, 399-404.

[9] Malumbres, M.; Pevarello, P.; Barbacid, M.; Bischoff, J.R. CDK inhibitors in cancer therapy: what is next? TRENDS in Pharmacological Sciences, 2007, 29(1), 16-21.

[10] Wyatt, P. G.; Woodhead, A. J.; Berdini, V. J.; Boulstridge, A.; Carr, M. G.; Cross, D. M. Identification of $\mathrm{N}$-(4-Piperidinyl)-4-(2,6-dichlorobenzoylamino)-1H-pyrazole3-carboxamide (AT7519), a novel cyclin dependent kinase inhibitor using fragment-based X-Ray crystallography and structure based drug design. J. Med. Chem., 2008, 51(16), 4986-4999.

[11] Pevarello, P. M.; Brasca, G.; Amici, R.; Orsini, P.; Traquandi, G.; Corti, L. 3-Aminopyrazole inhibitors of CDK2/CyclinA as antitumor agents. 1. Lead finding. J. Med. Chem., 2004, 47(13), 3367-3380

[12] Pevarello, P. M.; Brasca, G.; Orsini, P.; Traquandi, G.; Longo, A.; Nesi, M. 3-Aminopyrazole inhibitors of CDK2/CyclinA as an titumor agents. 2. Lead optimization. J. Med. Chem., 2005, 48(8), 2944-2956.

[13] Huang, X. F.; Lu, X.; Zhang, Y.; Song, G. Q.; He, Q. L.; Li, Q. S.; Yang, X. H.; Wei, Y.; Zhu, H. L. Synthesis, biological evaluation, and molecular docking studies of N-((1,3-diphenyl-1H-pyrazol-4-yl)methyl)aniline derivatives as novel anticancer agents. Bioorg. Med. Chem., 2012, 20(16), 4895-4900.

[14] Qian, D. Z.; Wang, X.; Kachhap, S. K.; Kato, Y.; Wei, Y.; Zhang, L.; Atadja, P.; Pili, R. The histone deacetylase inhibitor NVP-LAQ824 inhibits angiogenesis and has a greater antitumor effect in combination with the vascular endothelial growth factor receptor tyrosine kinase inhibitor PTK 787/ZK 222584. Cancer Res., 2004, 64, 6626-6634.

[15] Bali, P.; Pranpat, M.; Swaby, R.; Fiskus, W.; Yamaguchi, H.;
Balasis, M.; Rocha, K.; Wang, H. G.; Victoria, R.; Kapil, B. Activity of suberoylanilide hydroxamic acid against human breast cancer cells with amplification of her-2. Clin. Cancer Res., 2005, 11(17), 6382-6389.

[16] Cai, X.; Zhai, H. X.; Wang, J.; Forrester, J.; Qu, H.; Yin, L.; Lai, C. J.; Bao, R.; Qian, C. G. Discovery of 7-(4-(3-Ethynyl phenylamino)-7-methoxy quinazolin-6-yloxy)-N-hydroxy heptanamide (CUDC-101) as a potent multi-acting HDAC, EGFR, and HER2 inhibitor for the treatment of cancer. $J$. Med. Chem., 2010, 53(5), 2000-2009.

[17] Kristin, S. K.; Michael, E. S.; Kristoffer, R. B.; Matthew, B.S. Development of a Chimericc-Src Kinase and HDAC Inhibitor. ACS Med. Chem. Lett., 2013, 4(8), 779-783.

[18] Ning, C. Q.; Lu, C.; Hu, L.; Bi, Y. J.; Yao, L.; He, Y. J.; Liu, L. F.; Liu, X. Y.; Yu, N.F. Macro cyclic compounds as anti-cancer agents: Design and synthesis of multi-acting inhibitors against HDAC, FLT3 and JAK2. European Journal of Medicinal Chemistry, 2015, 95, 104-115.

[19] Lebedev, A. V.; Lebedeva, A. B.; Sheludyakov, V. D.; Kovaleva, E.A.; Ustinova, O.L.; Kozhevnikov, I.B. Synthesis of 3-substituted aryl pyrazole-4-carboxylic acids. Russian Journal of General Chemistry, 2005, 75(5), 782-789.

[20] Boumendjel, A.; Boccard, J.; Carrupt, P. A.; Nicolle, E.; Blanc, M.; Geze, A.; Choisnard, L.; Wouessidjewe, D.; Matera, E. L.; Dumontet, C. Antimitotic and Antiproliferative Activities of Chalcones: Forward Structure-Activity Relationship. J. Med. Chem., 2008, 51(7), 2307-2310.

[21] Dermatakis, A.; Luk, K. C.; DePinto, W. Synthesis of potent oxindole CDK2 inhibitors. Bioorg. Med. Chem., 2003, 11(8), 1873-1881.

[22] Zhou, M.; Ning, C.; Liu, R.; He, Y.; Yu, N. Design, synthesis and biological evaluation of indeno[1,2-d]thiazole derivatives as potent histone deacetylase inhibitors. Bioorg. Med. Chem. Lett., 2013, 23(11), 3200-3203.

[23] Ning, C.; Bi, Y.; He, Y.; Huang, W.; Liu, L.; Li, Y.; Zhang, S.; Liu, X.; Yu, N. Design, synthesis and biological evaluation of di-substituted cinnamic hydroxamic acids bearing urea/thiourea unit as potent histone deacetylase inhibitors. Bioorg. Med. Chem. Lett., 2013, 23(23), 6432-6435. 